\title{
PENGGUNAAN MEDIA PEMBELAJARAN SEBAGAI UPAYA MENCIPTAKAN PEMBELAJARAN AKTIF DI KELAS
}

\author{
Ana Nurhasanah ${ }^{1}$, Reksa Adya Pribadi ${ }^{2}$, Muhammad Ari Syahrial $^{3}$ \\ 1,2,3Pendidikan Guru Sekolah Dasar, Fakultas Keguruan dan IImu Pendidikan, \\ Universitas Sultan Ageng Tirtayasa \\ 1ananur74@untirta.ac.id, 2reksapribadi@untirta.ac.id, ${ }^{32227190035 @ u n t i r t a . a c . i d ~}$
}

\begin{abstract}
Learning media is a learning tool or device that can be used by teachers to assist them in conveying learning messages. This study aims to determine how the influence of learning media in creating active learning. This research was conducted using descriptive qualitative method. Data collection techniques in this study used interview and observation techniques. Based on the research that has been done, the implementation of learning at SDN Kebon Jahe, especially in class $V$, has used learning media that makes learning run active.
\end{abstract}

Keywords: Learning Media, Active Learning, Effective.

\begin{abstract}
ABSTRAK
Media pembelajaran dapat diartikan sebagai alat atau perangkat pembelajaran yang bisa digunakan guru dalam membantunya menyalurkan pesan pembelajaran. Penelitian ini bertujuan untuk mengetahui bagaimana pengaruh media pembelajaran dalam menciptakan pembelajaran aktif. Penelitian ini dilakukan dengan menggunakan metode kualitatif deskriptif. Teknik pengumpulan data dalam penelitian ini menggunakan teknik wawancara dan observasi. Berdasarkan penelitian yang telah dilakukan, pelaksanaan pembelajaran di SDN Kebon Jahe khususnya di kelas $\mathrm{V}$ telah menggunakan media pembelajaran yang
\end{abstract}


membuat pembelajaran berjalan aktif serta pembelajaran yang dilaksanakan menjadi lebih efektif.

Kata Kunci : Media Pembelajaran, Pembelajaran aktif, Efektif.

\section{A. Pendahuluan}

Dalam kegiatan pembelajaran, kegiatan interaksi antara guru dengan peserta didik tidak dapat dihindarkan dalam pelaksanaannya. Hal ini dikarenakan untuk menyampaikan pesan pembelajaran berupa materi harus disampaikan oleh guru melalui ucapan verbal agar pesan pembelajaran yang disampaikan guru dapat diterima dengan baik oleh peserta didik. Meski begitu, terkadang terdapat sebagian peserta didik yang tidak dapat mencerna apa yang disampaikan oleh gurunya tersebut. Hal ini dikarenakan peserta didik tidak memiliki gambaran mengenai materi apa yang disampaikan oleh gurunya tersebut dan peserta didik tersebut enggan untuk bertanya. Untuk mengatasi hal tersebut diperlukan adanya sebuah alat yang bisa digunakan guru untuk membantunya menyampaikan materi yang ingin disampaikan kepada peserta didik sehingga dapat dipahami oleh peserta didik. Alat tersebut biasa disebut dengan "Media Pembelajaran".

Media pembelajaran menurut Surayya, 2012 media pembelajaran merupakan suatu alat yang dipergunakan guru untuk membantunya dalam menjalankan proses belajar mengajar dimana fungsinya yaitu untuk memperjelas makna dari materi yang disampaikan. Sejalan dengan pendapat tersebut, Briggs dalam Akhmad Sudrajat, 2011 : 2012, mengemukakan bahwa media pembelajaran merupakan sebuah sarana fisik yang digunakan guru untuk menyampaikan materi ajar. Senada dengan pendapat tersebut, Steffi Adam dan Muhammad Taufik Syastra 2015 mengemukakan bahwa media pembelajaran adalah segala sesuatu baik itu yang berbentuk fisik ataupun teknis di dalam proses pembelajaran yang bisa membantu guru agar lebih mudah dalam menyampaikan materi pembelajaran 
kepada peserta didik dalam rangka mencapai tujuan pembelajaran yang sudah ditetapkan. Dari ketiga pendapat di atas mengenai pengertian media pembelajaran tersebut bisa diambil kesimpulan bahwasanya media pembelajaran merupakan sebuah alat atau perangkat pembelajaran yang bisa dipergunakan guru untuk membantunya dalam menyampaikan pesan pembelajaran berupa materi yang hendak disampaikan oleh guru kepada peserta didik.

Dari beberapa pendapat di atas mengenai arti dari media pembelajaran, kita dapat mengetahui betapa pentingnya media pembelajaran dalam menunjang pembelajaran agar materi ajar yang disampaikan guru kepada peserta didik dapat diterima dengan baik oleh peserta didik serta membuat pembelajaran berlangsung dengan efektif. Namun pada kenyataannya, tidak jarang terlihat guru yang masih kesulitan dalam menggunakan media pembelajaran yang digunakan sebagai alat bantu dalam menyampaikan materi ajar. Hal ini kemungkinan bisa terjadi dikarenakan guru yang masih belum sepenuhnya menguasai materi, kemudian kurangnya kreatifitas guru dalam membuat media pembelajaran yang relevan dengan materi yang akan disampaikan. Untuk mengatasi masalah tersebut, guru hendaknya menguasai terlebih dahulu materi yang akan disampaikan kepada peserta didik sebelum pelaksanaan pembelajaran dan guru sebaiknya lebih memikirkan untuk membuat media apa yang cocok untuk dikaitkan dengan materi yang akan disampaikan. Dengan begitu, permasalahan tersebut dapat teratasi.

Pada saat ini, dunia sedang dalam masa "Pandemi". Menurut KBBI (Kamus Besar Bahasa Indonesia) pandemi merupakan wabah yang berjangkit serempak di mana-mana, meliputi daerah geografi yang luas. Pandemi ini seringkali kita dengar dengan nama "Covid-19" atau "Corona". Virus corona merupakan sebuah penyakit yang bisa menular yang disebabkan oleh virus SARSCoV-2. Sebagian orang yang tertular virus ini mengalami gejala ringan sampai sedang dan bisa pulih tanpa dibutuhkan penanganan khusus dari tim medis. Namun jika sudah memasuki tahap gejala berat, sebagian orang akan mengalami 
sakit begitu parah dan memerlukan bantuan medis. Maka dari itu pemerintah menerapkan protokol kesehatan ketat untuk meminimalisir tertularnya wabah tersebut dengan cara pembatasan kegiatan yang dilakukan berkerumun, tak terkecuali kegiatan pembelajaran.

Kegiatan pembelajaran di masa pandemi ini menggunakan sistem "daring". Jadi sistem pembelajaran ini dilaksanakan dari jarak jauh tanpa adanya tatap muka, melainkan tatap maya yang dapat dilakukan melalui perangkat keras seperti Handphone, Laptop dan lainlain. Sistem pembelajaran ini dianggap sistem yang paling efektif di masa pandemi ini dikarenakan pembelajaran dilakukan di rumah masing-masing tanpa berkerumun di dalam satu ruangan agar tidak ada peserta didik yang terjangkit wabah covid-19. Namun, sistem pembelajaran daring ini tentunya memiliki kelemahan dalam pelaksanaannya yaitu kegiatan belajar mengajar antara guru dan peserta didik dapat terhambat karena sinyal internet masing-masing, serta memakan kuota internet yang cukup besar hanya dalam satu kali pertemuan saja. Hal inilah yang menjadi

hambatan

dalam pembelajaran sistem daring tersebut. Selain itu, media pembelajaran yang dapat digunakanpun agak sedikit berbeda daripada sebelumnya. Biasanya media pembelajaran yang digunakan guru dalam sistem pembelajaran tatap muka beragam dan dapat dilihat secara langsung oleh peserta didik. Sedangkan dalam pembelajaran jarak jauh tidak dapat dilihat secara langsung, melainkan melalui perantara perangkat lunak saja. Maka dari itu guru dituntut lebih kreatif lagi dalam merancang dan membuat media pembelajaran dalam sistem pembelajaran saat ini.

Media pembelajaran pada pembelajaran jarak jauh ini dapat berupa video animasi pembelajaran yang digunakan untuk menarik minat siswa untuk menyimak isi materi. Kemudian dapat menggunakan media berupa powerpoint yang dapat guru tampilkan pada saat pertemuan tatap maya. Powerpoint dibuat semenarik mungkin dan materi yang dicantumkan dalam powerpoint tersebut hanyalah point pentingnya saja. Hal ini dilakukan agar siswa dapat menanyakan terkait materi yang disampaikan. Hal itulah yang 
dapat membuat pembelajaran menjadi lebih aktif.

\section{B. Metodologi Penelitian}

Penelitian ini dilaksanakan di SDN Kebon Jahe yang beralamat di Jl. KH. Abdul Hadi - Kebon Jahe, Cipare, Kec. Serang, Kota Serang, Prov. Banten. Penelitian ini dilakukan pada bulan November 2021. Sumber data primer penelitian ini diperoleh dari siswa-siswi kelas $\mathrm{V}$ dan wali kelas di kelas $V$. Penelitian ini dilakukan dengan menggunakan metode kualitatif deskriptif.

Metode kualitatif ini diartikan sebagai penelitian yang dimana peneliti dijadikan sebagai instrumen kunci. Menurut Maleong, metode kualitatif bertujuan untuk memahami suatu fenomena dengan mengutamakan proses interaksi komunikasi antara si peneliti dengan subjek penelitian. Lalu dalam teknik pengumpulan data, teknik yang digunakan peneliti meliputi teknik observasi dan teknik wawancara.

Wawancara dilakukan peneliti dengan salah satu guru di SDN Kebon Jahe yang bernama Ibu Eti Sulaesiah, S. Pd. Beliau merupakan wali kelas di kelas $\mathrm{V}$ SDN Kebon Jahe. Dalam pengumpulan data, peneliti mengumpulkan data penelitian melalui dua sumber, yaitu dari informan atau narasumber, dan melalui kegiatan pembelajaran di kelas.

\section{Hasil Penelitian dan \\ Pembahasan}

Pada bulan November 2021, peneliti melakukan pengamatan di SDN Kebon Jahe. Peneliti melakukan wawancara secara langsung dengan wali kelas di kelas $\mathrm{V}$ SDN Kebon Jahe yang bernama Ibu Eti Sulaesiah S. Pd. Dalam wawancara ini peneliti bertanya mengenai apa saja permasalahan yang terjadi pada saat pembelajaran berlangsung. Peneliti memfokuskan pertanyaan mengenai media pembelajaran dan keaktifan peserta didik di kelas.

Menurut beliau penggunaan media pembelajaran di SDN Kebon Jahe sangat berpengaruh dengan jalannya proses pembelajaran sehingga pembelajaran dapat berjalan aktif dan pembelajaran tidak hanya terpusat pada guru melainkan berpusat pada peserta didik (Student Center). Menurut Beliau, dalam memilih media pembelajaran haruslah disesuaikan dengan materi 
apa yang akan disampaikan agar pembelajaran bisa berjalan dengan baik.

Namun seperti yang kita ketahui sebelumnya, kita pada saat ini sedang berada dalam masa pandemi yang mewajbkan pembelajaran dilakukan di rumah masing-masing. Untuk menghadapi situasi seperti ini, beliau memilih untuk menggunakan media pembelajaran berjenis audio visual. Menurut Wina Sanjaya (2010:172) media berjenis audio visual adalah media yang memiliki unsur suara dan gambar yang dapat dilihat, contohnya rekaman video, slide, suara, dan lainlain. Alasan beliau memilih media audio visual ini dikarenakan media berjenis ini mudah menarik minat serta perhatian peserta didik sehingga proses pembelajaran dapat berlangsung aktif dan efektif.

Menurut pemaparan guru tersebut, media yang digunakan pada pembelajaran jarak jauh ini yaitu media berjenis audio visual dimana alasan pemilihan media tersebut dikarenakan untuk menarik minat dan perhatian peserta didik dalam menunjang pembelajaran yang mendorong peserta didik untuk berperan aktif dalam kegiatan pembelajaran. Kemudian beliau menceritakan pengalaman dalam mengajar salah satu peserta didiknya yaitu pembelajaran tidak menggunakan media dengan pembelajaran menggunakan media. Hasilnya sangat terlihat bahwa beliau harus mengulangi pembelajaran pada saat tidak menggunakan media pembelajaran. Hal ini dikarenakan kebanyakan siswa tidak paham akan materi yang disampaikan guru tersebut.

Kemudian, peneliti kembali melakukan kunjungan ke SDN Kebon Jahe untuk melakukan penelitian berupa observasi pembelajaran di kelas. Peneliti melakukan pengamatan guru yang mengajar di kelas $\mathrm{V}$. Dari apa yang peneliti amati, sebelum pembelajaran dilaksanakan 
guru tersebut sudah merancang RPP.

Rencana Pelaksanaan Pembelajaran (RPP) merupakan rencana yang menggambarkan sebuah prosedur, serta pengorganisasian pembelajaran yang dilakukan untuk mencapai satu kompetensi dasar yang telah ditetapkan. Peneliti melihat guru tersebut sedang mengajarkan peserta didiknya yang mana materi yang diajarkan yaitu materi “Jam”.

Dalam penyampaiannya, guru tersebut menggunakan media pembelajaran berupa jam dinding untuk dijadikan sebagai alat peraga atau alat bantu guru tersebut dalam menyampaikan materi yang akan disampaikan. Hasilnya, pembelajaran bisa dikatakan berjalan dengan aktif, dimana guru tersebut tidak hanya menjelaskan isi materi, tetapi di tengah penyampaiannya terdapat pertanyaan yang dilontarkan kepada beberapa peserta didik. Peserta didik pun terlihat dapat menjawab pertanyaan yang diberikan dengan benar. Disamping penggunaan media pembelajaran,

guru

tersebut menggunakan model pembelajaran aktif.

Model pembelajaran aktif merupakan suatu model pembelajaran yang memberikan kesempatan kepada siswa untuk berperan lebih aktif pada saat pembelajaran berlangsung dengan menyediakan lingkungan belajar yang membuat siswa tidak tertekan dan merasa senang pada saat melaksanakan kegiatan pembelajaran.

Sehingga dapat diketahui bahwa jalannya pembelajaran ditentukan oleh kreatifitas guru dalam merancang pembelajaran serta dalam menggunakan media dan cara penyampaiannya. Hal ini dilakukan agar peserta didik berminat serta tertarik untuk mengikuti kegiatan pembelajaran sehingga memberikan dampak berupa pembelajaran aktif. 
D. Kesimpulan

Dari hasil penelitian yang telah peneliti lakukan, dapat ditarik kesimpulan bahwa pembelajaran di SDN Kebon Jahe dengan menggunakan media pembelajaran dapat membuat jalannya kegiatan belajar mengajar menjadi lebih aktif, efektif dan berjalan menarik. Pembelajaran lebih berpusat pada peserta didik dan peran guru dalam pembelajaran hanya sebatas fasilitator yang dapat membantu peserta didik untuk belajar dan memiliki keterampilan-keterampilan yang diperlukan untuk mencapai tujuan pembelajaran. Adapun guru kelas $\mathrm{V}$ yaitu Ibu Eti Sulaesiah S. Pd telah melakukan tugas mengajar dengan baik dimana beliau sudah menyiapkan RPP sebelum kegiatan pembelajaran dilaksanakan dan mengimplementasikannya dengan baik, serta menggunakan media pembelajaran yang tepat sesuai dengan materi yang disampaikan.

\section{DAFTAR PUSTAKA}

Raehang. 2014. Pembelajaran Aktif Sebagai Induk Pembelajaran Koomperatif. Jurnall Al- Ta'dib. Vol. 7 No.1, hal.156.

Tafonao, Talizaro. 2018. PERANAN MEDIA PEMBELAJARAN DALAM MENINGKATKAN MINAT BELAJAR MAHASISWA. Jurnal Komunikasi Pendidikan, Vol. 2 No. 2. hal. 105.

Din, Reza Muhammad Gusti Panuntun \& Achmad Mujab Masykur. 2016. DINAMIKA PSIKOLOGIS MAHASISWA BERPRESTASI: Studi Kualitatif Deskriptif. Jurnal Empati, Volume 5 No. 1.

Purwono, Joni. dkk. 2014. PENGGUNAAN MEDIA AUDIO - VISUAL PADA MATA PELAJARAN ILMU 
PENGETAHUAN ALAM DI

SEKOLAH MENENGAH

PERTAMA NEGERI 1

PACITAN. Jurnal Teknologi

Pendidikan dan Pembelajaran.

Vol. 2 No. 2 hal.128

Kariadi, Dodik \& Wasis Suprapto. 2018. Model Pembelajaran Active Learning Dengan Strategi Pengajuan Pertanyaan Untuk Meningkatkan Kualitas Proses Pembelajaran Pkn. Jurnal EducatiO. Vol. 12 No. 1 hal.16

Wahid, Abdul. 2018. PENTINGNYA MEDIA PEMBELAJARAN DALAM MENINGKATKAN PRESTASI BELAJAR. Jurnal Istiqra'. Volume 5 Nomor 2. 